\title{
Research Paper Economics and constraint analysis of non traditional maize farmers in Mahbubnagar district under Tank of Andhra Pradesh
}

See end of the paper for authors' affiliations

Correspondence to : I. SHAKUNTALA DEVI Department of Agricultural Economics, College of Agriculture, Rajendranagar, HYDERABAD (TELANGANA) INDIA

Paper History :

Received : 15.01.2016;

Revised : 01.02.2016;

Accepted : 12.02 .2016
AвSTRACT : This paper has been drawn from part of work done by the authors to assist Varsha NGO, Hyderabad in project on the value chain analysis of maize with an objective to study the economics of maize farmers cultivating under tank irrigation and constraints faced by them in Mahbubnagar district. The study showed that out of total cost of cultivation of Rs. 32041.23 per hectare, the operational costs contributed 84.41 per cent and the remaining 15.59 per cent by fixed costs. Farmers secured a net benefit cost ratio of Rs. 0.56 , i.e., receiving Rs. 0.56 for every rupee invested in maize cultivation. Small farm holdings and limited resource availability and vagaries of monsoon like drought associated with highest cost on labour increased pressure of diseases/pests are the major constraints faced by the farmers in the study area.

KEY Words : Constraints, Economics, Maize, Profitability, Tank irrigation

How To Cite This PAPer : Devi, I. Shakuntala and Suhasini, K. (2016). Economics and constraint analysis of non traditional maize farmers in Mahbubnagar district under Tank of Andhra Pradesh. Internat. Res. J. Agric. Eco. \& Stat., 7 (1) : 86-90. 